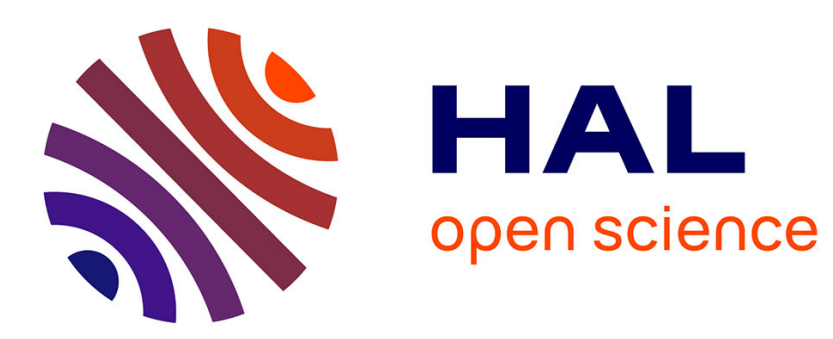

\title{
Running for Freedom: The Politics of Long-Distance Running in Modern Fiction
}

Alexis Tadié

\section{To cite this version:}

Alexis Tadié. Running for Freedom: The Politics of Long-Distance Running in Modern Fiction. International Journal of the History of Sport, 2014, 32 (2), pp.286-298. hal-02006404

\section{HAL Id: hal-02006404 \\ https://hal.sorbonne-universite.fr/hal-02006404}

Submitted on 4 Feb 2019

HAL is a multi-disciplinary open access archive for the deposit and dissemination of scientific research documents, whether they are published or not. The documents may come from teaching and research institutions in France or abroad, or from public or private research centers.
L'archive ouverte pluridisciplinaire HAL, est destinée au dépôt et à la diffusion de documents scientifiques de niveau recherche, publiés ou non, émanant des établissements d'enseignement et de recherche français ou étrangers, des laboratoires publics ou privés. 


\title{
Running for freedom : the politics of long-distance running in modern fiction ${ }^{1}$
}

\author{
Alexis Tadié \\ Department of English, University of Paris-Sorbonne, Paris, France \\ alexis.tadie@paris-sorbonne.fr; Maison de la Recherche, 28, rue Serpente, 75006 \\ Paris, FRANCE.
}

Keywords: Running. Fiction. Heroes. Sillitoe. Echenoz. McNeish. Glanville.

\begin{abstract}
This essay analyses the uses of running in contemporary fiction. It addresses the question of the literariness of running, and the ways in which literature enables us to articulate aspects of the sport such as its heroism or its relationship to the nation. It looks at a number of fictional texts, and focuses largely on two important works, "The Loneliness of the Long-Distance Runner", Sillitoe's celebrated novella of 1958, and Jean Echenoz's novel, Running, published 50 years later. This essay examines the quality of running defined in literature, then looks at its traditional function of celebration of heroes, before closing on the freedom associated with running in such works.
\end{abstract}

Alexis Tadié is professor of English literature at the University of Paris-Sorbonne and a senior research fellow at the Institut Universitaire de France. He is a specialist of eighteenthcentury literature and philosophy, and also works on the relationship between literature and sport. He edited with J.A. Mangan and Supriya Chaudhuri a special issue of the International Journal of the History of Sport, Sport, Literature, Society: Historical Perspectives (2012). 
The camera's eye Does not lie,

But it cannot show

The life within,

The life of a runner,

Of yours or mine,

That race which is neither fast nor slow, ${ }^{2}$

In Fanny Burney's Evelina (1778), two characters organise a race between old ladies, which is the object of a bet between them:

The place marked out for the race, was a gravel-walk in Mrs. Beaumont's garden, and the length of the ground twenty yards. When we were summoned to the course, the two poor old women made their appearance. Though they seemed very healthy for their time of life, they yet looked so weak, so infirm, so feeble, that I could feel no sensation but that of pity at the sight. However, this was not the general sense of the company, for they no sooner came forward, than they were greeted with a laugh from every beholder, Lord Orville excepted, who looked very grave during the whole transaction. ${ }^{3}$

This scene contrasts the main characters, Evelina and Lord Orville, who are preoccupied to the point of disgust, and the company, who enjoy the proceedings and laugh at the scene. It reminds us that the modes of laughter in the eighteenth century could involve cruelty. ${ }^{4}$ But it also rests on certain customs linked to the organisation of races. Like most sports, races in the late eighteenth century were usually the object of bets and wagers, in fact were organised with such aims. The courses were not standard (in this particular instance, twenty yards), were part of private grounds or attached to a public house. Runners were usually gentlemen's footmen who were raced by the nobility. But there was also a practice of "freak races", where the runners were deemed to be ridiculous or had a ridiculous handicap. One such race, held in 1660 on Newmarket Heath, involved two disabled men and was attended by the king 
himself:

At 3 of the clock in the afternoon there was a foot-race between 2 cripples, each having a wooden leg. They started fair and hobbled a good pace, which caused great admiration and laughter among the beholders, but the taller of the two won by 2 or 3 yards. $^{5}$

Although it dramatises the reactions of the various characters, the episode in Evelina rests on now forgotten practices of running and races. It reminds us that there is a long history to the sport, as well as it suggests a function, for literature, of repository of such history.

But the literature of sport addresses other issues as well, enlightening us as to various practices, celebrating sports and heroes, bringing an understanding of the figures of sport thanks to a mode of discourse which makes extensive use of the "figure" as a principle of writing. Running concentrates most of the issues of modern sport. It raises questions of gender ${ }^{6}$ (as when testing for DNA a woman to find out whether she might not really be a man), of class (one of the elements in the rivalry between Steve Ovett and Sebastian Coe, for instance), of race, of philosophy and ethics (when do feet stop being feet?), of drugs, of money (amateurs vs professionals, money paid and reinvested, bets and bribes), of national identity, etc. Some of these questions are best addressed by the historian or the sociologist of sport. My concern, here, is more with the relationship between literature and running, with the specific light that literature may cast on the sport. In this essay, I have chosen not to address all the instances of running in literature, which range from the Indian runner, close to the heart of Fenimore Cooper, to the runner of the "overnight mail", celebrated by Kipling in a famous poem, or again to the go-between of L.P. Hartley's novel. They are numerous, and have been partly covered by Roger Robinson in his survey of 
running in literature. ${ }^{7}$ I have concentrated instead on the sport, on the ways in which literature enables us to reach a better understanding of running as a sport, but also, conversely, on the ways in which the sport may illuminate literature.

This paper addresses the question of the literariness of running, the ways in which literature enables us to articulate aspects of the sport, its heroism, its relationship to the nation, its essence perhaps. It looks at a number of texts that approach running, and focuses largely on two important works of fiction, "The Loneliness of the Long-Distance Runner", Sillitoe's celebrated novella of 1958, and Jean Echenoz's novel, Courir ${ }^{8}$ published 50 years later. This essay focuses on the quality of running defined in literature, on its traditional function of celebration of heroes, before closing on the freedom of running.

\section{The quality of running}

In "The Loneliness of the Long-Distance Runner", Alan Sillitoe offers a complex meditation on the experience of running. He focuses on the solitary position of the runner, as he prepares to leave a dormitory where everyone is still asleep: "I feel like the first and the last man on the world, both at once, if you can believe what I am trying to say." ${ }^{9}$ He feels like the first man on earth because he stands there, in the frozen morning, almost naked, ready to embark upon a two-hour run. He feels like the last man on earth, because he imagines that his mates are all dead, that he is the only one left, and that everything is going to revert to the ice-age. And he sets off, preferring to concentrate on the "first man" feeling. He describes his running as something instinctive, dream-like, "turning at lane or footpath corners without 
knowing I'm turning, leaping brooks without knowing they're there, and shouting good morning to the early cow-milker without seeing him." (10; my emphasis) Sillitoe emphasises the rhythm of the run through the ternary repetitions of sounds which readers can hear, as they can hear the gentle sounds of Smith's stride: “Trot-trot-trot. Puff-puff-puff. Slap-slap-slap go my feet on the hard soil. Swish-swish-swish as my arms and side catch the bare branches of a bush." $(11)^{10}$ It is almost a flight, a birdlike quality that he is after: "it's the most wonderful minute because there's not one thought or word or picture of anything in my head while I'm going down." (17) On his runs, he reaches that state where everything is so smooth that he forgets he is running or racing, but is only jog-trotting along. It is an experience of honesty.

A similar experience of flight is encountered in a poem about the most famous runner of Ancient Greece, Robert Browning's "Pheidippides". The poem celebrates the runner who may have brought the news of the victory of the battle at Marathon, ${ }^{11}$ and who, like Smith later, experiences for a while the perfect run: "Such my cry as, rapid, I ran over Parnes' ridge;/Gully and gap I clambered and cleared.” Having seen the god Pan, he resumes with alacrity: "But enough! He was gone. If I ran hitherto- $/$ Be sure that the rest of my journey, I ran no longer, but flew. Parnes to Athens/Earth no more, the air was my road." The smoothness of the experience, the perfection of running are also embodied in the final cry, which hails both the military victory and the running feat: "Rejoice, we conquer!" The poem celebrates Pheidippides and his run, the making of a hero.

Emil Zatopek, who is the subject and the main character of Echenoz's novel, Running, is a different type of hero. He was never a smooth runner. He is reported to have said of his running style: "I shall learn to have a better style once they start judging races according to their beauty. So long as it's a question of speed then my 
attention will be directed to seeing how fast I can cover ground." ${ }^{12}$ His style was a constant reminder of the pain he experienced when running. ${ }^{13}$ A long description captures the effort involved:

There are runners who seem to fly, others who seem to dance, still others who look as if they were parading, and some appear to be advancing as though they were sitting on top of their legs. There are those who simply look as if they've been summoned and are hurrying as fast as possible. Emil, nothing like all that.

Emil, you'd think he is excavating, like a ditch digger, or digging deep into himself, as if he were in a trance. Ignoring every time-honored rule and any thought of elegance, Emil advances laboriously, in a jerky, tortured manner, all in fits and starts. ${ }^{14}$

The narrator pursues relentlessly the appearance of the runner, to try and restore to the written word the rhythm of this exceptional running style: "Never, ever, anything like the others, even if he is a guy like everyone else." (47)

Thus, literature endeavours to recapture and define what it sees as the nature, the rhythm, the appearance and the experience of running. The metaphoric nature of the description of running in Sillitoe is counter-balanced by the external point of view adopted by Echenoz, who tries to describe, as accurately as possible, the nonAcademic style of Zatopek. Browning's celebration of Pheidippides's achievement is also a celebration of the dream-like quality of his running. And all three authors, precisely, find in the style of running the foundations of their own narrative styles. For Sillitoe, running is a metaphor of writing, the rhythm of running dragging his pen along the page. The relationship between running and writing constitutes as well the central motif of the text, since the story is not only about the hero's rebellion against the system, but also about the resistance involved in the act of writing. As the narrator puts it: "I'd like to see the governor's face when he reads it." In shaping the anger and 
the rebellion against the social forces that restrict the freedom of the working classes, Sillitoe positions his tale of the Borstal boy as the very act of resistance against the hypocrisies of the society of the late 1950s. On the other hand, Echenoz's reconstruction of the career of Zatopek allows him to explore, from the point of view of a post-communist world, the workings of communist society and of the historical pressures that define and restrict one, exceptional, individual.

\section{Heroes of the nation}

But runners are also heroes, and celebrated as such. Smith is, at first, the hero of his Borstal, the great hope that both the administration of the school and the kids have of winning the cup. Zatopek becomes the hero of the Czech nation, celebrated everywhere, even when, having been punished by the Communists for his open support to Dubcek, he collects rubbish. Browning's poem to Pheidippides appears in the line of epinician poetry that celebrated the heroes of Antiquity, "gloriously as he began,/So to end gloriously." ${ }^{\prime 15}$ Such poetry praised wealthy athletes on their return from the Panhellenic games and were aimed at glorifying athletic victory for the entire community; it was therefore central to the definition of civic virtue. ${ }^{16}$ But the poem can also be read against the grain, as suggested by Helen Small, who argues that the last stanza "shifts the accent of the long-distance runner's story away from the renewal of the health and security of the civic state to the private desires of the runner - seen at the last as young, ardent, touchingly naive, not unreservedly to be admired." $" 17$ 
The Olympian, Brian Glanville's novel about a fictional runner, investigates the contradictions of long-distance running through the progress of Ike Low, a young runner who is made into an international celebrity by his coach, Sam Dee. Ike later foresakes the unconventional Sam for a German advocate of scientific interval training, before going back to Sam just before the 1964 Tokyo Olympics, where, aged 26, he hopes to win the Olympic medal which eluded him in Rome because of injury. Sam's position is contrasted with that of the official trainers of the British delegation, as well as with, more crucially, that of Jill, a young female runner whom Ike Low marries. The narrative alternates points of view in order to approach a full picture of the world of running: Ike's own narrative, Sam's direct speech, journalists' accounts and interviews, scenes written in the manner of a theatre play or a film-script, with settings and dialogues, while fellow-runner Alan's narrative perspective conveys to the reader a more distanced gaze on Ike's progress and plight.

The difficulties of the running world are outlined, the necessity to earn money in particular, and the tricks used by athletes to circumvent the amateur rule - a number of athletes, such as Jules Ladoumègue, who was banned from taking part in the 1932 Olympic Games, or Paavo Nurmi, who could not run the Marathon at the same Olympic Games, were prevented from competing because they were deemed to have infringed the rules of amateurism. The fights within the world of athletics surface regularly, and are underlined by Alan: "If people asked me to characterise the athletics world in one word, I suppose it would be "hatred." (96). Sam's antagonistic methods are prompt to generate such difficulties: "this remarkable moulder of champions, who can rouse love and hatred with equal facility, whose eccentric ways have led to so many bitter battles with officialdom." (109) 
Sam advocates a vision of athletics and of training which is based on a metaphysic of running. Not only because he insists on the necessity of training in beautiful surroundings, free of the tyranny of the watch, but because he finds in athletics and in records the full dimension of human potential: "And that is why athletics are important, why records are important. Because they demonstrate the scope of human possibility; which is unlimited. The inconceivable is conceived, and then it is accomplished." (8) Kurt, the German trainer, imparts a vision of athletics based on interval training, on the dictatorship of the clock, which Ike finds, at first, liberating: “I wanted to run, only in a way I wouldn't feel as good as I thought I would, because out at this place with Kurt, I'd suddenly begun to feel free, in a way I hadn't done for years." (214) But he later loses the pleasure of running, having been turned into a sort of machine: "The joy's gone out of his running, again; he's a circus horse, prancing round the ring, plumed and splendid, but doing it under duress. For Kurt: the kind animal trainer." (262) Both coaches constitute two facets of the same problem with coaching, the will to control the athletes who, in turn, want to be treated like children. Alan formulates the Faustian dimension of the world of athletics: "For now I can see the temptations, can see how awfully easy it is to find oneself playing God; by tacit request." (278)

The literary attempt to penetrate the nature of the sport, through the focalisation on the mind of a runner, is also apparent in James McNeish's narrative of the destiny of Jack Lovelock, the celebrated New Zealand runner. First published in 1986, on the fiftieth anniversary of the Berlin Olympic games when Lovelock won a gold medal and broke the world record over $1500 \mathrm{~m}$, the eponymous novel Lovelock charts the progress and downfall of the runner. Helped by Lovelock's diaries, ${ }^{18}$ which are occasionally quoted verbatim, and a significant amount of research, McNeish has 
constructed the story of this famous runner into a fictional autobiography which starts with Lovelock's Oxford days, and his first race against non-University opposition. Like Echenoz's novel about Zatopek, McNeish's uses the ressources of fiction to construct Lovelock into a novelistic character. The race represents, as in a number of novels about sport, a moment of epiphany for the young runner: "I had no plan for now, just speed. Only speed. I was running on air. I had never felt like this before."19 The novel tracks his progress, his fight against time, his aspiration to run in the Los Angeles Olympic Games, his lack of experience, ${ }^{20}$ his further mistakes in preparing for various races, all seen as "fumbling steps towards rebuilding [his] selfconfidence." (158) He experiments with modes of training, introducing swimming into his routine for instance, before developing the idea of the literary "perfect race" as he nears the Berlin Olympiads: "Now a story in a book, a story by Chesterton, for example, that can be perfect. I think a race should be built like a book, to be remembered." (228) The comparison with literature, in which we can hear the voice of the novelist, brings about the idea of long-lasting fame, of perfection in the manner and not only in the result, thereby hinting at the literary construction of the novel, as celebration of that perfect race. It charts the progress of his great idea ("something of value was being hatched inside me" 249), the understanding of the fundamental fact of athletics running: "Maybe I was lucky in having finally become aware that the winner of the last race is already forgotten as soon as the next one starts." (id.) The planning of the race starts months before, five months exactly, with, in particular, the idea of the sprint over the last lap suddenly becoming the key to the race itself, sustained by critical analysis of all the Olympic races on record: "I found that not only had it not been done before, nobody appeared to have attempted anything like it." (259) But the description of that moment of grace, of trance, is here as elsewhere one 
of transcendence of gravity and friction, one where "I seemed to be gliding, totally weightless.” (349)

The first person narrative aims at reproducing the inner world of the athlete, his doubts and frailty as well as his knowledge of the races that no newspaper accounts can approach, the characteristic obsession with time, his chronic insomnia as well as the revelations they bring about, his hesitations over which distance to run (1500 or 5000 metres), the logic of the race, its slowness for runners as opposed to its quickness for spectators. But somehow the artificiality of the reconstruction transpires, when the narrator refers to Riefenstahl's film during the description of the Olympic race (349) or in the last part, as we approach Lovelock's death. ${ }^{21}$

Sillitoe's celebration of the long-distance runner is rather more ambiguous than that offered by McNeish's Lovelock. The novella relates the sportsman to the idea of the nation as embodied in the institution of the Borstal, with its governors and modes of functioning and its rules and its fences. In this sense, "The Loneliness of the Long-Distance Runner" may also be seen as a distant reply to Tom Brown's

Schooldays, a questioning of the role of the games ethic in education; it looks back, in particular, at the "Big-side hare and hounds" game, an ancestor of cross-country running. Sillitoe's narrator spells out clearly his relationship to the institution, not hating it, he says, but resenting it for what it does to him, for being the essence of the nation: "what it does do is show me what they've been trying to frighten me with." (15) The Borstal embodies social relationships and class relationships, and the "war" that is fought by one part of society against the other. It brings together class-enemies, the coppers and the Borstal-bosses and "the rest of them bastard-faced In-laws" (11).

The whole story is built on the tensions between an inner self and an outer self, between an inner revolt and an outside compliance, between the world of the 
working class and the world of the rulers of society, between the appropriation of Smith by the governors of the school and his inner rejection of them. And the setting for the race encapsulates all the aspects of sport as a national institution, complete with flag, betting, and self-satisfaction:

So the big race it was, for them, watching from the grandstand under a fluttering Union Jack, a race for the governor, that he had been waiting for, and I hoped he and all the rest of his pop-eyed gang were busy placing big bets on me, hundred to one to win, all the money they had in their pockets, all the wages they were going to get for the next five years, and the more they placed the happier I'd be.

As opposed to the narrator's initial lyrical moments about the essence of running, the reality of running as a spectator's sport is here suggested, with its dominant concerns for jingoism and financial returns - which, of course, go back to the origins of running as a sport. It is this tension that Smith's attitude finally solves by refusing to win the race, bringing the outside reality of society to conform to his inner self, defeating the reality of running in order to achieve victory, or better, as he says, "honesty": "I know what honest means according to me and he only knows what it means according to him." (14) The rebellion is complete, and unlike in the film where it is seen but not heard, in the novella, the inner voice of the unrepentant Borstal boy conveys the meaning of an otherwise incomprehensible rebellion: "I'm a human being and I've got thoughts and secrets and bloody life inside me that he doesn't know is there." (12) The tension which inhabits Smith is of greater magnitude than, say, that of Glanville's Olympian, because running, as encapsulated in the reference to the Union Jack, organised running at least, belongs to the Nation, to the institutions which, along with Borstals and governors, are at war with the working classes. Thus considered, sport is just a means of control, rather than the promise of 
emancipation hypocritically advocated by the governors and the coaches. This is Sillitoe:

Society was built on "competition", and "sport" is a preliminary to this society and an accompaniment to it. It is a sort of training ground for entering into the war of life. The Olympic torch is a flame of "enslavement"-run from it as fast as you can, and that in itself will give you plenty of exercise. ${ }^{22}$

Smith's act of resistance can thus be read as resistance to the incarceration regime of the Borstal, to the further incarceration in store through winning the prize ${ }^{23}$ and as resistance to organised sport itself with its competitions and its prizes and its athletes being treated worse than race horses (8). Through his rebellion, Smith condemns sport as precisely one of the elements of the Nation that is at war with him — and perhaps his class. The working-class defiance expressed by Smith connects with other Sillitoe characters, such as Arthur in Saturday Night, Sunday Morning, who look for modes of rejecting the pressures of society. These texts resonate in the context of the prosperity of England in the late 1950s, as a questioning of Britain's modernity, as a political means of undermining the workings of society, and as a contribution to the cultural climate otherwise encapsulated by such writers as the "Angry young men." But like Arthur's, Smith's act of resistance is ultimately an individual one, and does not connect with a sense of collective rebellion.

The tension between running and the nation is at the heart of Echenoz's novel, which opens with the invasion of Moravia by the Nazis. Echenoz's Emil at first works in a shoe factory, and is forced by the owners to take part in an annual promotion race. He shares his father's hatred for sport, "a sheer waste of time and —above all— money." (8) But the Nazis have set up sporting activities in which Emil is forced to take part, his first race pitting a well-trained, well-equipped German team against the 
poor, ill-equipped young Czechs. He finishes second, without really noticing it. And he gets caught in the process, perhaps a way, as the narrator suggests, of thinking of something other than the destruction brought about by the Nazis. He trains, does not practice his style, which is awful, but his speed — "if you're going to run, might as well run fast, right?" (20-1) After the liberation by the Soviets, Emil joins the army for national service, then the Academy to train as an officer, and beats some local records over $3,000 \mathrm{~m}$ and $5,000 \mathrm{~m}$. He is put up, against his will, for the European championships: "he doesn't feel up to the job and so would rather not accept." (30) Unlike other delegations, the Czechs don't even own a tracksuit, and have to take part in the parade wearing their shorts. He finishes fifth: "Emil could be proud of himself, but as usual he isn't.” (33) By now, Emil, who improves Czech national records regularly, has become a celebrity, people fight to see him run. Because he is the sole representative of Czechoslovakia in the Allied forces championships, the flag-bearer is pretty disgusted at having to walk in front of a delegation of one, and when they penetrate the stadium, everybody laughs. But Emil, slightly irritated by the disparaging treatment of the organisers, wins the race, lapping most of the competitors, becomes an idol, of the flag-bearer as well, who is now proud of parading in front of this athlete.

The novel outlines the peculiarities of his training. Although Zatopek did not invent interval training, he was the first athlete systematically to train at a harder pace than race-pace, so as to make the race feel easy. The novel also investigates the intricate links between running and politics. Because athletes are important to the Eastern block as tools for propaganda, Emil becomes "Athlete of the State," (50) is given perks, promotions in the army, and facilities to train. He wins the $10,000 \mathrm{~m}$ at the London Olympics, defeating the great Finnish runner Heino, and wins a silver in 
the 5,000. Then Emil beats Heino's world record over 10,000m, heralded as a victory for "real socialism". This is when the exponents of real socialism start thinking that he travels too much, that he shouldn't take part in as many races, that perhaps he will be tempted to defect. It is the time of the brutal repression by the Czech communist party, the time of Gottwald and Stalin. Emil is a member of the party: "One shouldn't dismiss Emil as an opportunist. Two things are absolutely indisputable: that he sincerely believes in the virtues of Socialism, and that in his position he could hardly do otherwise." (60) He travels and beats world records, but only in the socialist countries; he is under constant surveillance.

Helsinki. Emil is 30, a little tired, but he flies off to the Olympic Games, accompanied by the officials that never leave him when he is abroad. Emil has enrolled in the $5,000 \mathrm{~m}$, the $10,000 \mathrm{~m}$, the marathon. Wins the first two, although he is quite tired, and takes the start of the third, which he has never run before. And which he wins, seemingly easily, although, unlike any other runner, he does not show the pain he has endured. Emil has become a national hero, he goes round factories, to show that he is "real", which means that he is the product of communism. This is the time of the great trials, and Emil is asked to say that he will never accept another invitation from a non-Eastern country: "Cold war, Iron Curtain, Emil is obviously not going for a little stroll abroad." (77) So he beats world records at home, owns all the records above and including the 5,000m (nine in all). Stalin and Gottwald die, Emil can run abroad again. He is manipulated by journalists, very nearly cannot run in France, but he breaks the world record over $5,000 \mathrm{~m}$ in Paris. And then he starts losing races, growing old perhaps, announces that he will retire after the Melbourne Olympics. On marathon day, Emil is spent, stops, starts again, and finishes sixth. Later, Emil, still a very popular man in the country, declares himself in favour of 
Dubcek. And the last chapter of this novel, which had opened on the invasion of the Nazis, describes the invasion of the Soviet forces and the end of the Prague spring. Emil is sent to work in uranium mines, where he toils for six years, then is allowed to come back to Prague, where he is given a job as a dustman but he is too popular, so he is sent to the country, to dig holes for telegraph poles, before being asked to sign a confession.

This is a political novel, which outlines the destructions brought to Czechoslovakia by the various forces of occupation, and the position and the struggle of an individual in this context. This is a sports novel that tracks the progress and the training and the performances and the essence of running. This is a novel about sports and the nation, about the manufacturing or the appropriation of a hero, and about the pressures and the contradictions and the undermining of a hero. It is not a biography of Zatopek, whose surname is only mentioned once, but it is a novel which uses the ressources of fictional biography and the devices of external narration to make us think about sport and the nation and resistance. ${ }^{24}$ Emil is the exact opposite of Smith. Smith decides not to win the race to avoid being caught in the process of sport as a mode of domination. Emil wins everything, in spite of the forms of control exerted on him by society. But both are ambiguous heroes of the nation, whose sporting achievements create for them a privileged if untenable position.

Whereas Smith can be seen as an anti-hero, in that he refuses to become the hero of a system which he opposes and fights, Emil cuts the complex figure of a hero celebrated for his sporting achievements, who is crushed by the system because of the risks presented to the regime by his fame. Echenoz's tale resonates in the context of a historical investigation of the celebration of athletes in communist countries, but in the $21^{\text {st }}$ century as well, when the cult of heroes structures the sporting world. 
Sillitoe's defiant portrayal of sport as one of the forces that rule society, and the individual resistance of his central character, is echoed by Echenoz's use of sport to investigate the historical workings of communism, and the powerlessness of his equally lonely hero.

\section{Running for freedom}

The nature of running, because of the individual nature of the sport, favours the maverick or the rebel. If Sillitoe and Echenoz both investigate the uneasy relationship between the runner and the nation, embodied in Zatopek's case by the communist state, and in Smith's by Borstal, they redefine sport through fiction, suggesting ways in which fiction, perhaps a contrario, can capture the essence of the sport, its inherent freedom.

The intricacies of running and politics are of course addressed by McNeish who tries to have his hero reflect, modestly, on his participation in the 1936 Olympic Games. The narrative makes room for a description of some of the important events in the Games, such as the long jump contest between Owens and Long. There are echoes of the political situation, and of the argument about boycotting the Games, but registered by Lovelock rather than argued for or against (265). The ceremony of the games is related from Lovelock's point of view, although the novelist declares his inability to revive it: "The march-past has since become history. Who can describe it?" (306) Or rather, it is envisaged with a touch of irony, since Lovelock, the flagbearer, did not recognise Hitler and saluted the wrong person - which is read as an act of defiance by some. The description of the Olympic Games echoes the arguments about boycott, about appeasement and joint celebrations, about the treatment afforded 
to Jewish, African and African-American competitors, dramatizing from the perspective of one, not particularly involved competitor, the political dimension of sports. A meeting with the former runner Otto Peltzer, who had been imprisoned for homosexuality, brings out the activities of the Resistance during the Olympic Games, and contrasts the attitude of the former sportsman turned opponent to the Nazi regime with Lovelock's own attitude: “I keep forgetting you are only a sportsman, says Peltzer. In Germany it is no longer possible to be only a sportsman." (383) The last part of the book, after Lovelock has retired, returns to the frailty of the man, to both his physical and mental condition, and ends with the ambiguities of his death, under the wheels of a New York subway. ${ }^{25}$

It is a paradox, but a literary productive one, that the freedom of running can be put forward within the context of a Borstal, or within the context of the communist state. Sillitoe's narrator voices this from the start: "Sometimes I think that I've never been so free as during that couple of hours when I'm trotting up the path out of the gates and turning by that bare-faced, big-bellied oak tree at the lane end." (10-1) And even though, like Emil, his punishment is to carry dust-bins around every morning, he has won the fight against the governor, he is free to be himself, unrepentent. The experience of freedom is conveyed to the reader by the device of first-person narration; the thoughts and memories and analyses of Smith are made directly available to the reader, forcing the reader to, if not an identification, an understanding of, or an empathy with, a clearly defined point of view. The work of fiction, in this instance, is to offer the reader a form of thought-experiment. Running and writing, in Sillitoe's conception, come to be united in this quest for honesty, in the position of the writer as rebel, as ultimately free: 
The theme of the story [is] really [. . . ] about a writer, but you can't write about a writer so I put my hero into a borstal and all around him the borstal attitudes were the attitudes of society and what they expected of him, and what they expected and hoped that he would believe. But he fought against it. He knew, he realised, that the only value is to keep your own integrity. It was really an extended essay on the integrity of a person in prison, in borstal, or if you like the integrity of a writer. ${ }^{26}$

In The Olympian, Ike's perception of running is imparted through first-person narration which borders at times on indirect free speech, providing a form of running commentary on the races: "Old Sam there, I heard him as I passed, 'Stay there. Stay with those four.' I feel good. The way he always said. Like I was flying, like something else took over. Like I could go right out in front of the lot of them, now."27 The pleasure and the beauty of running are achieved through the superior state that is reached by the runner, and best experienced through the metaphor of flying which combines the lightness of running with a sense of power associated with that experience:

I needed these races, though, they gave me a feeling I couldn't get nowhere else; that power coming up inside you, jogging along with the rest and smiling to yourself inside, thinking just you wait, you wait till I go, and the moment when you did go, the flying moment when you were off on your own, the wind in your face, and knowing this was it, they couldn't live with you. (78-9; emphasis in the text).

Alan's view of the proceedings introduces on the scene of the novel a literary perspective given by the power of myth. At one stage, he compares the triangle formed by Ike, Jill and Sam to a morality play: "Ike as Everyman, Jill the good angel, Sam the tempter. Type-cast, of course; sometimes I've felt Jill shone with goodness, quite oppressively, while Sam, the temper, had most of the best tunes.” (174-5) This suggests that the story of the young runner acquires a dimension that exceeds athletic 
feats. The novel induces a reflection on life through the superimposition of myths, where the sportsman is the new hero of ancient myths — Everyman in this instance. But this is where the description of running and the literary perspective on sport come together, in the flight which is achieved by Ike in these moments of transcendence. His flight is both the glide of the runner on the track, who reaches a moment of grace, of epiphany, and the hubris of Icarus, whose rise brings about his fall. And indeed, Ike's nightmare is one where he is falling, hinting at his last words in the Olympic final, the last words of the novel: "Not running any more. Just falling, falling." (310) Emil's freedom rests first and foremost on his obsessive individualism. He is described as an ordinary guy, normal and shy and retiring, but determined to do things his own way, train his own way, run races his own way. Running allows the author to examine the contradictions between the obsessive individualism of his main character and the pressures of society and of politics. Fiction allows the author to examine the contradictions of running, a sport caught between its fundamental individuality and a system submitted to the forces of politics and of history. The narrative never addresses (unattainable) motives, but it describes circumstances. In constructing Zatopek, or rather Emil, into the main character in a fiction, Echenoz suggests both the frivolity of going on the internet to check the facts, ${ }^{28}$ and a deeper understanding, perhaps, of the nature of running, this most individual of sports.

In its most perfect moments, running is an experience of least resistance, of abolition of friction, regularly described as a flight by writers and novelists - to the point, perhaps, of cliché. But it is an ambivalent flight, one that is contrasted with the constraints of Smith's Borstal, one which, Icarus-like, precludes the eventual fall of the runner. In order to approach such moments of epiphany, novelists sometimes use 
the first-person narrative as the literary means through which to convey the experience of running. At the same time, this imposes constraints on the narrative, in particular for The Olympian, which varies points of view in order the gain a fuller picture, but which finds itself at the end, somewhat artificially, turning the ending into an interruption. ${ }^{29}$ McNeish's perspective on Lovelock, resting on the appearance of fictional autobiography, in turn, means that the novelist must find a way for his character to tell the story of his own death - a not particularly successful outcome in this instance.

All descriptions of races tend towards the immediate, towards the ideal simultaneity of running and writing (or speaking). It is this aspiration which Glanville, McNeish and Sillitoe strive for through the choice of first-person narrative. But Smith's revolt against the forces of oppression, and the victory he achieves through the refusal of victory, undermine the temptation to have writing and running coincide. His ironical stance reintroduces a distance between running, and writing about running, in the same way that Echenoz's largely external description of Emil turns the narrative into a problem rather than a solution. If the choice of first-person narrative enables Glanville or McNeish to investigate the epiphany of running, Sillitoe's and Echenoz's fictions rely on the important dimensions of narrative and ironical distance. No writing can coincide with running, especially when the main protagonist is a character whose real-life results may be remembered by the reader. Acknowledging this distance, both Sillitoe and Echenoz, differently, turn the question of running into a literary issue.

But this is of course something that the Queen had told us long ago: "Now, here, you see, it takes all the running you can do, to keep in the same place. If you want to get somewhere else, you must run at least twice as fast as that." ${ }^{30}$ 
${ }^{1}$ A version of this essay was presented at the "Sport and the Nation" conference organised at Jadavpur University in 2012 by Professor Supriya Chaudhuri.

${ }^{2}$ Auden, "Runner", 612.

${ }^{3}$ Burney, 311.

${ }^{4}$ See Dickie, Cruelty and Laughter.

${ }^{5}$ Report in the Loyal Protestant. Quoted in Edward S. Sears, 52.

${ }^{6}$ See Chaudhuri.

${ }^{7}$ Roger Robinson, Running in Literature, New York, Breakaway books, 2003. See also Garth Battista, The Runner's Literary Companion [1994] (New York: Penguin, 1996).

${ }^{8}$ Jean Echenoz, Running, tr. Linda Coverdale (London, New York: The New Press, 2013).

${ }^{9}$ Sillitoe, "The Loneliness of the Long-Distance Runner", 8.

${ }^{10}$ See Sillitoe, 12 where the sounds are repeated. See also p. 37, p. 39, p. 43.

${ }^{11}$ It is also possible to suggest, as Roger Robinson has speculated, that the poem itself played a role in the introduction of the marathon at the first ever Olympic games, in 1896, in Athens. See Robinson, 118.

${ }^{12}$ Quoted in Sears, 217.

${ }^{13}$ One reporter wrote of Zatopek: "Zatopek ran like a man who had been stabbed through the heart." (Sears, 217)

${ }^{14}$ Echenoz, Running, 44.

${ }^{15}$ The great example of celebration of a runner in English literature is A.E. Housman's poem “To an Athlete Dying Young." In this elegy, the poet laments the untimely death of his lifelong love, Moses Jackson. It moves beyond the simple celebration of athletics to mourn the passing of the young, and to address the grief of the persona.

${ }^{16}$ See Papakonstantinou.

${ }^{17}$ Small, 136.

${ }^{18}$ See David Colquhoun and Peter Snell, eds. As If Running on Air: The Diaries and Journals of Jack Lovelock (Nelson: Craig Potton Publishing, 2008).

${ }^{19}$ McNeish, 79.

20 "I seemed to be either too far ahead or too far back. My brain cleared and I made a snap decision to stick with Cunnigham, resolved to follow the flat of his head; but I felt bustled. The blare of the speaker had thrown me, upsetting the rhythm of my stride." (136) 
${ }^{21}$ There are other inconsistencies, such as when the narrator refers to Harris's book, published after the death of Lovelock, or Peltzer's time in India, again, after the death of Lovelock.

${ }^{22}$ Quoted in Hughson, 44.

${ }^{23}$ Winning "means running right into their white-gloved wall-barred hands and grinning mugs and staying there for the rest of my natural long life of stone-breaking anyway."

${ }^{24}$ This novel is the second in a trilogy of fictional biographies composed by Echenoz. See Ravel and Lightning. In these books, Echenoz concentrates on the French composer Maurice Ravel, on the runner Emil Zatopek, and on the Electrical engineer and inventor, who in particular developed alternating current, Nikola Tesla. In all three works, the author treats these historical characters as fictional characters, constructing a peculiar relationship between fiction and truth. One of the inspirations for such narratives is John Aubrey's Brief Lives, written in the second half of the seventeenth century.

${ }^{25}$ Although the conclusion was that it was an accident, the hypothesis of a suicide cannot be totally ruled out ; see McNeish's "Afterword to the 2009 edition."

${ }^{26}$ Voice commentary for The Loneliness of the Long Distance Runner, quoted in Small, 141.

${ }^{27}$ Glanville, 45, my emphasis. All references are to this edition.

${ }^{28}$ Strikingly, the novel contains no facts, no times, no records.

${ }^{29}$ This is a device that Glanville uses as well for the ending of The Dying of the Light.

${ }^{30}$ Carroll, 210.

\section{References}

Auden, W. H. "Runner" in Collected Poems. London: Faber \& Faber, 1976, 609-12.

Battista, Garth. The Runner's Literary Companion (1994). New York: Penguin, 1996.

Burney, Fanny. Evelina or the History of Young Lady's Entrance into the World (1778) edited by Edward A. and Lillian D. Bloom. Oxford: Oxford University Press, 1968.

Carroll, Lewis. Through the Looking-Glass (1871). Harmondsworth: Penguin, 1982. Chaudhuri, Supriya. "Bodies at Risk: Gender and Sport." In Women Contesting Culture: Changing Frames of Gender Politics in India, edited by Kavita 
Panjabi and Paromita Chakravarti, 181-198. Kolkata: Stree and School of Women's Studies, Jadavpur University, 2012.

Colquhoun, David and Peter Snell, eds. As If Running on Air: The Diaries and Journals of Jack Lovelock. Nelson: Craig Potton Publishing, 2008.

Connor, Steven. A Philosophy of Sport (London: Reaktion Books, 2011)

Dickie, Simon. Cruelty and Laughter. Forgotten Comic Literature and the Unsentimental Eighteenth Century. Chicago: University of Chicago Press, 2011.

Echenoz, Jean. Ravel. Translated by Linda Coverdale. New York; London: The New Press, 2007.

---. Running. Translated by Linda Coverdale. London, New York: The New Press, 2013.

---. Lightning. Translated by Linda Coverdale. New York; London: The New Press, 2011.

Glanville, Brian. The Olympian [1969] (London: Faber\&Faber, 2010),

Hughson, John. "The 'Loneliness' of the Angry Young Sportsman.” Film \& History $2005,35,(2)$

McNeish, James. Lovelock (1986). London: Quartet Books, 2012.

Murakami, Haruki. What I Talk about when I Talk about Running. Translated by Philip Gabriel. London: Vintage, 2009.

Papakonstantinou, Zinon. "The Athletic Body in Classical Athens: Literary and Historical Perspectives." In International Journal of the History of Sport, vol. 29, $\mathrm{n}^{\circ} 12,1657-68$. Issue edited by Alexis Tadié, J.A. Mangan and Supriya Chaudhuri.

Robinson, Roger. Running in Literature. New York: Breakaway books, 2003.

Sears, Edward S. Running through the Ages. Jefferson and London: McFarland \& Co., 2001.

Sillitoe, Alan. "The Loneliness of the Long-Distance Runner." in The Loneliness of the Long-Distance Runner (1958). London: Star book, 1975.

Small, Helen. "The Loneliness of the Long-Distance Runner in Browning, Sillitoe, and Murakami." Essays in Criticism 60 (2): 129-47. 